\title{
FAKTOR YANG MEMPENGARUHI KEJADIAN DIARE DI TAMBAK SARI, KOTA
} SURABAYA

\section{INFLUENCING FACTORS TOWARD DIARRHEA CASES IN TAMBAKSARI, SURABAYA CITY}

\author{
Debby Daviani Prawati1), Dani Nasirul Haqi2)
}

\begin{abstract}
${ }^{1}$ Departemen Biostatistika dan Kependudukan Fakultas Kesehatan Masyarakat, Universitas Airlangga, Surabaya

2Departemen Kesehatan dan Keselamatan Kerja Fakultas Kesehatan Masyarakat, Universitas Airlangga, Surabaya

E-mail: debby.daviani.dd@gmail.com
\end{abstract}

\begin{abstract}
Background: Diarrhea is an illness which characterized by changed in shape, consistency of the stool and with excessive bowel frequency (more than 3 times within a day). Diarrhea disease is the third contributor of children's morbidity and mortality rate around the world. Purpose: This study aims to analyzing factors that caused diarrhea's cases. This research were an observational analytic type. Sampling technique were used random sampling / probability sampling. Methods: Data were analyzed by chi-square test. Data collection techniques were divided into primary data (direct observation and questionnaire) and secondary data (journals and articles). Results: On this research showed there's no significant correlation between sex, age, education, income, hand washing behavior using soap, clean water facility and trash bin condition with diarrhea occurrence during last 3 months in RW.VI Kelurahan Rangkah Buntu, Surabaya. There were a significant relation between cleaning up the environment, making and consuming oralit, and the behavior of handwashing with soap before meals at the rate of diarrhea cases during the last 3 months in RW VI Kelurahan Rangkah Buntu, Surabaya. Conclusion: there's no significant correlation between social demography, behavior using soap, clean water facility and trash bin and a significant relation between clean up the environment, behavior handwashing, making and consuming oralit during the last 3 month in RW VI Kelurahan Rangkah Buntu, Surabaya.
\end{abstract}

Keywords: diarrhea, predisposing factors, behavior, action, environment.

\begin{abstract}
ABSTRAK
Latar Belakang: Diare merupakan penyakit dimana ditandai dengan perubahan bentuk dan konsistensi tinja dan dengan frekuensi buang air besar berlebihan (lebih dari 3 kali dalam kurun waktu satu hari). Penyakit diare merupakan penyumbang ketiga angka kesakitan dan kematian anak di dunia. Tujuan: Penelitian ini bertujuan untuk meneliti tentang faktor yang mempengaruhi kejadian diare. Metode: Penelitian ini merupakan tipe observasional analitik. Teknik pengambilan sampel menggunakan random sampling / probability sampling. Analisis data dengan menggunakan uji chi-square. Teknik pengumpulan data dibedakan menjadi data primer (pengamatan langsung dan kuesioner) dan data sekunder (jurnal dan artikel). Hasil: Hasil dari penelitian ini tidak ada hubungan yang signifikan antara jenis kelamin, usia, pendidikan, pendapatan, perilaku mencuci tangan menggunakan sabun, sarana air bersih serta kondisi tempat sampah dengan kejadian diare selama 3 bulan terakhir di wilayah RW VI Kelurahan Rangkah Buntu, Kota Surabaya. Terdapat hubungan yang signifikan antara membersihkan lingkungan, membuat dan mengonsumsi oralit, dan perilaku cuci tangan pakai sabun sebelum makan pada angka terjadinya diare selama 3 bulan terakhir di wilayah RW VI Kelurahan Rangkah Buntu, Kota Surabaya. Kesimpulan: tidak ada hubungan signifikan antara sosial demografi, perilaku menggunakan sabun, air bersih dan keadaan sampah dan terdapat
\end{abstract}


hubungan yang signifikan antara lingkungan bersih, perilaku mencuci tangan, membuat dan mengonsumsi oralit selama 3 bulan terakhir di RW VI Kelurahan Rangkah Buntu, Surabaya.

Kata Kunci: diare, faktor predisposisi, perilaku, tindakan, lingkungan.

\section{PENDAHULUAN}

Penyakit diare di Indonesia masih menjadi masalah kesehatan yang sangat menarik untuk dikaji dan dilihat penyebab serta menemukan solusi untuk penyembuhannya. Notoatmojo pada tahun 2004 mengatakan bahwa usia balita termasuk umur dengan kondisi rawan gizi dan mudah tertular penyakit infeksi.

Diare merupakan penyakit yang ditandai dengan berubahnya bentuk tinja dengan intensitas buang air besar secara berlebihan (lebih dari 3 kali dalam kurun waktu satu hari). Penanganan cepat sangat dibutuhkan untuk mengatasi penyakit diare karena apabila terlambat maka akan dapat menyebabkan kekurangan cairan yang dapat menyebabkan kematian. Dalam negara berkembang penyakit diare ada balita menjadi penyebab kedua angka sakit dan kematian.

Suratmaja pada tahun 2007 menyebutkan bahwa pada kasus penyakit diare akut, mikroorganisme akan masuk ke saluran cerna, kemudian mikroorganisme akan berkembang biak karena telah mampu melewati asam lambung. Mikroorganisme tersebut akan membentuk racun kemudian menyebabkan rangsang terhadap mukosa usus yang menyebabkan munculnya hiperperistaltik. Sekresi cairan pada tubuh inilah yang mengakibatkan terjadinya penyakit diare.

Faktor risiko yang dapat menimbulkan penyakit diare adalah faktor lingkungan, faktor perilaku pada masyarakat, rendahnya pengetahuan masyarakat tentang diare serta malnutrisi. Contoh dari faktor-faktor lingkungan yang buruk misalnya kondisi sanitasi yang tidak memenuhi syarat maupun fasilitas sarana prasarana air bersih yang tidak memadai. Faktor-faktor perilaku masyarakat seperti jarang mencuci tangan ketika akan makan dan setelah buang air besar serta melakukan pembuangan tinja dengan cara yang salah. Tanpa pemberian air susu ibu secara eksklusif terutama selama 4 sampai 6 bulan pertama dapat meningkatkan risiko terjangkit penyakit diare lebih besar. Hal ini diakibatkan oleh kurangnya kemampuan ibu untuk mencari tahu tentang penyakit diare yang biasa terjadi pada anak-anak (Adisasmito, 2007).

Target cakupan pelayanan pasien penyakit diare yang berobat ke fasilitas kesehatan dan tenaga kesehatan adalah $10 \%$ dari perkiraan total seluruh penderita diare. Insidensi diare nasional hasil Survei Morbiditas penyakit diare pada tahun 2014 yaitu sebesar 270/1.000 penduduk, maka diperkirakan jumlah penderita diare di fasilitas kesehatan pada tahun 2016 sebanyak 6.897 .463 orang, sedangkan jumlah penderita diare yang dilaporkan ditangani di fasilitas kesehatan adalah sebanyak 3.198.411 orang atau 46,4\% dari target (Profil Kesehatan Provinsi Jawa Timur, 2016). Penyakit diare yang dapat diobati di Kota Surabaya pada tahun 2015 adalah 65.447 kasus dari total 60.960 perkiraan kasus yang ditemukan (Profil Kesehatan Kota Surabaya, 2016).

Penelitian lain di SD Advent Sario juga didapatkan bahwa terdapat 29\% mengalami diare. Penyebab diare di SD tersebut adalah siswa yang tidak terbiasa mencuci tangan menggunakan sabun (Ilham dkk, 2014). Beberapa penyebab diare dibagi menjadi 6 sebab besar, yaitu infeksi, malabsorbsi pada usus, keracunan, immunodefisiensi, faktor perilaku, dan faktor lingkungan (Depkes RI, 2007).

Lawrence Green membagi faktor perilaku menjadi tiga faktor yaitu predisposing factor, enabling factor serta reinforcing factor. Predisposing factor merupakan faktor yang terdapat dalam diri masing-masing individu yang dapat memotivasi individu tersebut untuk melakukan sebuah tindakan misalnya usia, jenis kelamin, pendidikan, status sosial dan tingkat ekonomi, sikap dan pengetahuan. Enabling factor adalah kondisi yang memungkinkan tersedianya sarana dan prasarana yang dapat memicu seseorang untuk melakukan sebuah perubahan tindakan contohnya adalah pelayanan kesehatan dan media informasi. Pengertian reinforcing factor yaitu faktor yang dapat menguatkan individu tersebut untuk 
memperkuat motivasi untuk melakukan perubahan tindakan seperti adanya peraturan ataupun kebijakan.

Salah satu cara untuk bisa mencegah terjadinya diare adalah dengan cara mencuci tangan menggunakan sabun. Menurut WHO pada tahun 2005 ada 2 cara mencuci tangan yaitu mencuci tangan dengan menggunakan sabun serta air dan mencuci tangan dengan cairan yang mengandung alkohol. Tujuan mencuci tangan menurut Depkes RI tahun 2007 adalah salah satu unsur pencegahan penularan infeksi. Penyakit diare harus dikendalikan agar dapat mengurangi kejadian kesakitan dan kematian dengan cara kerja sama lintas program dan lintas sektor. Cakupan layanan penyakit diare dalam kurun waktu 6 tahun terakhir mengalami peningkatan yang cukup pesat yaitu tahun 2013 yaitu cakupan layanan mampu mencapai $118 \%$. Hal ini terjadi karena ada penurunan angka morbiditas dari tahun 2012 yang 411/1.000 penduduk menjadi 214/1.000 penduduk pada tahun 2013.

Capaian cakupan pelayanan diare terendah di Provinsi Jawa Timur terjadi pada tahun 2016 yaitu sebesar 82\%. Hal ini disebabkan oleh rendahnya ketepatan dan kelengkapan laporan bulanan dari Kabupaten/Kota. Persentase penggunaan oralit dalam 6 tahun terakhir mengalami peningkatan namun demikian angka penggunaan infus juga tinggi (Profil Kesehatan Provinsi Jawa Timur, 2016).

Data dari Profil Kesehatan Kota Surabaya tahun 2016 menjelaskan bahwa Kecamatan Tambaksari dipilih dikarenakan kecamatan ini memiliki jumlah penduduk paling besar dan padat di Kota Surabaya. Dalam Kecamatan Tambaksari terdapat 3 kelurahan, yaitu Kelurahan Rangkah, Kelurahan Pacar Keling, dan Kelurahan Gading. Kelurahan Rangkah dipilih dikarenakan berdasarkan data dari Dinas Kesehatan Kota Surabaya pada tahun 2016 menempati posisi kedua penduduk terpadat di wilayah Kecamatan Tambaksari namun memiliki kejadian diare paling besar.

Penentuan prioritas masalah dilakukan bersama Ketua RW, Ketua RT, dan Kader RW VI. Hasil penentuan prioritas masalah yang diperoleh adalah kejadian diare menempati tempat kedua. Hal ini menunjukkan bahwa masih banyak kejadian diare di RW VI Kelurahan Rangkah.

Penelitian yang dilakukan oleh Anik dkk (2017), telah membuktikan bahwa membersihkan tangan menggunakan sabun dengan penyakit diare pada murid sekolah dasar memiliki hubungan. Hal tersebut juga sejalan dengan penelitian yang dilakukan oleh Arry dkk (2013) yang menyatakan bahwa perilaku membersihkan tangan menggunakan sabun dengan kejadian diare pada Kecamatan Blora memiliki hubungan yang signifikan. Padahal efektifitas kebiasaan atau perilaku bersih dengan CTPS dapat mencegah pola penyebaran penyakit menular di masyarakat, seperti penyakit diare.

Penelitian ini dilakukan dengan tujuan untuk mengetahui faktor-faktor yang berpengaruh pada penyakit diare di RW VI Kelurahan Rangkah, Surabaya. Dengan diketahuinya faktor-faktor perilaku yang berpengaruh kejadian diare diharapkan masyarakat akan sadar dan paham bahwa mencuci tangan pakai sabun dengan baik dan benar akan mencegah dari diare.

\section{METODE}

Penelitian ini merupakan penelitian observasional analitik. Penelitian tersebut hanya melihat ataupun mengamati tanpa memberikan perlakuan atau treatment. Berdasarkan waktunya, penelitian ini termasuk dalam rancangan studi cross sectional karena semua kegiatan dilakukan dalam satu waktu (sesaat).

Penelitian ini dilakukan pada bulan Januari hingga Februari 2018. Populasi penelitian ini didasarkan dari seluruh Kartu Keluarga (KK) RW VI Kelurahan Rangkah Buntu yang diwakili satu orang per KK sehingga populasi dalam penelitian ini berjumlah 447 orang Pengambilan sampel dilakukan dengan metode simple random sampling dengan perhitungan menggunakan rumus Slovin dan didapat 211 responden yang ditetapkan menjadi sampel. Metode pengumpulan data dilakukan dengan wawancara dan observasi langsung menggunakan form observasi dan lembar kuesioner.

Peneliti hanya melakukan observasi yang memperhatikan faktor faktor yang berhubungan dengan kejadian diare dalam 3 bulan terakhir. Faktor - factor 
tersebut adalah predisposing factor yang meliputi jenis kelamin, usia, pendidikan, pendapatan, pengetahuan, sikap, tindakan dan kebiasaan. Faktor kedua adalah enabling factor yang meliputi ketersediaan sarana air bersih dan keadaan tempat sampah.

Penelitian ini menggunakan dua jenis sumber data, yaitu data primer dan data sekunder. Data primer didapatkan dari wawancara mendalam, lembar kuesioner dan lembar observasi. Data sekunder didapatkan dari data demografi warga RW VI Kelurahan Rangkah, Tambaksari, Surabaya.

Pengetahuan diukur dengan menggunakan pertanyaan benar atau salah yang terdiri dari 5 pertanyaan. Pengetahuan dikatakan baik jika pertanyaan yang terjawab benar $>75 \%$, cukup $60-75 \%$ dan kurang $<60 \%$. Pengetahuan responden baik jika menjawab benar >4 pertanyaan, cukup jika menjawab benar 3 pertanyaan dan kurang jika menjawab $\leq 2$ pertanyaan. Sikap diukur dengan menggunakan skala likert. Sikap dikategorikan baik jika skor menunjukkan > median dan kurang jika skor $\leq$ median. Median adalah nilai yang diperoleh dari hasil penjumlahan antara

Tabel 1. Distribusi Frekuensi Karakter Responden di Kelurahan Rangkah Buntu Tahun 2018

\begin{tabular}{lrc}
\hline \multirow{2}{*}{ Karakteristik } & \multicolumn{2}{c}{ Responden } \\
\cline { 2 - 3 } Jenis Kelamin & F & $\%$ \\
Laki-laki & 26 & 12 \\
Perempuan & 185 & 88 \\
\hline Usia & & \\
12-17 tahun & 1 & 1 \\
18-40 tahun & 83 & 39 \\
41-65 tahun & 101 & 48 \\
> 66 tahun & 26 & 12 \\
\hline Pendidikan & & \\
Rendah & 65 & 30,8 \\
Menengah & 40 & 19,0 \\
Tinggi & 106 & 50,2 \\
\hline Pendapatan & & \\
$<$ 500.000 & 28 & 13,3 \\
500.000-1.000.000 & 37 & 17,5 \\
1.100.000-1.500.000 & 39 & 18,5 \\
1.600.000-2.000.000 & 34 & 16,1 \\
$>$ 2.000.000 & 73 & 34,6 \\
\hline
\end{tabular}

skor minimal dan skor maksimal kemudian dibagi dalam kategori yang diinginkan. Sikap dikatakan baik jika skor $>14$ dan kurang jika skor $\leq 14$.

Tabel 2. Distribusi Faktor Predisposing Factor terhadap Kejadian Diare Rangkah

\begin{tabular}{|c|c|c|c|}
\hline \multirow{2}{*}{$\begin{array}{c}\text { Variabel } \\
\text { Independen }\end{array}$} & \multicolumn{2}{|c|}{$\begin{array}{l}\text { Kejadian } \\
\text { Diare }\end{array}$} & \multirow[t]{2}{*}{ Total } \\
\hline & $\mathrm{Ya}$ & Tidak & \\
\hline \multicolumn{4}{|l|}{ Jenis Kelamin } \\
\hline Laki-laki & 8 & 18 & 26 \\
\hline Perempuan & 50 & 135 & 185 \\
\hline \multicolumn{4}{|l|}{ Usia } \\
\hline 12-17 tahun & 13 & 30 & 43 \\
\hline 18-40 tahun & 20 & 60 & 80 \\
\hline 41-65 tahun & 14 & 47 & 61 \\
\hline$>66$ tahun & 11 & 16 & 27 \\
\hline \multicolumn{4}{|l|}{ Pendidikan } \\
\hline Rendah & 21 & 44 & 65 \\
\hline Menengah & 9 & 31 & 40 \\
\hline Tinggi & 28 & 78 & 106 \\
\hline \multicolumn{4}{|l|}{ Pendapatan } \\
\hline$<500.000$ & 9 & 19 & 28 \\
\hline $\begin{array}{l}500.000- \\
1.000 .000\end{array}$ & 7 & 30 & 37 \\
\hline $\begin{array}{l}1.100 .000 \\
1.500 .000\end{array}$ & 12 & 27 & 39 \\
\hline $\begin{array}{l}1.600 .000- \\
2.000 .000\end{array}$ & 6 & 28 & 34 \\
\hline$>2.100 .000$ & 24 & 49 & 73 \\
\hline \multicolumn{4}{|l|}{ Pengetahuan } \\
\hline Baik & 27 & 86 & 113 \\
\hline Cukup & 15 & 20 & 35 \\
\hline Kurang & 16 & 47 & 63 \\
\hline \multicolumn{4}{|c|}{ Sikap (Membersihkan Lingkungan) } \\
\hline Baik & 33 & 138 & 171 \\
\hline Kurang & 25 & 15 & 40 \\
\hline \multicolumn{4}{|c|}{$\begin{array}{l}\text { Sikap (Membuat dan mengonsumsi } \\
\text { Oralit apabila Diare) }\end{array}$} \\
\hline Baik & 3 & 44 & 47 \\
\hline Kurang & 55 & 109 & 164 \\
\hline \multicolumn{4}{|c|}{$\begin{array}{l}\text { Cuci Tangan Pakai Sabun Sebelum } \\
\text { Makan }\end{array}$} \\
\hline Ya & 20 & 29 & 49 \\
\hline Tidak & 38 & 124 & 162 \\
\hline \multicolumn{4}{|c|}{ Cuci Tangan Pakai Sabun Setelah BAB } \\
\hline Ya & 53 & 143 & 196 \\
\hline Tidak & 5 & 10 & 15 \\
\hline
\end{tabular}


Teknik analisis data menggunakan statistik deskriptif untuk mendapat tabulasi silang dan uji chi-square dan fisher exact test untuk mengetahui apakah terdapat hubungan antara variabel yang diteliti dengan munculnya penyakit diare dalam 3 bulan terakhir.

\section{HASIL DAN PEMBAHASAN}

RW VI Kelurahan Rangkah memiliki luas wilayah sebesar 4 Hektar. Wilayahnya terbagi menjadi 7 RT (Rukun Tetangga). Jumlah KK yang ada di RW VI adalah sebanyak $447 \mathrm{KK}$ dengan rincian per RT yaitu 58 KK (RT II), 57 KK (RT III), 81 KK (RT IV), 105 KK (RT V), 102 KK (RT VI) dan 44 KK (RT VII).

Responden penelitian adalah warga RW VI, dengan persentase $12 \%$ laki-laki dan $88 \%$ perempuan. Usia dibagi menjadi 4 kategori yaitu 12-17 tahun, 18-40 tahun, 41-65 tahun, dan >66 tahun. Pendidikan dibagi menjadi 3 kategori yaitu rendah (SD/SMP), menengah (SMA/SMK) dan tinggi (D3/S1). Pendapatan menjadi 5 kategori seperti dalam tabel 1. Observasi lingkungan dilakukan di 211 rumah dan mengambil satu orang dari tiap rumah untuk dilakukan wawancara mengenai pola kebiasaan atau perilaku sehari-hari terkait kejadian diare.

Tabel 2 dan 3 merupakan hasil distribusi frekuensi karakteristik responden di Kelurahan Rangkah Buntu Surabaya. Hasil yang didapat adalah frekuensi kejadian diare pada masing-masing variabel independen yang digolongkan menjadi dua faktor. Faktor yang pertama adalah predisposing factor yang meliputi jenis kelamin, usia, pendidikan, pendapatan, pengetahuan, sikap dalam membersihkan lingkungan, sikap dalam mengonsumsi oralit, mencuci tangan menggunakan sabun setelah buang air besar dan mencuci tangan dengan sabun sebelum makan. Faktor yang kedua enabling factor yang meliputi ketersediaan air bersih dan keadaan tempat sampah pada 211 responden dengan kejadian diare dalam 3 bulan terakhir.

Hasil tabel tabulasi silang atau tabel distribusi faktor diatas dapat dilakukan perhitungan menggunakan SPSS, sehingga dapat diketahui nilai chi-square maupun nilai fisher exact masing-masing variabel independen yang diteliti. Pada tabel 4 dan 5 dibawah ini merupakan nilai chi-square maupun nilai fisher exact beserta hubungan antar variabel masing-masing variabel independent predisposing factor dan enabling factor yang diteliti.

Faktor-faktor yang memiliki hubungan terhadap penyakit diare di Kelurahan Rangkah Buntu, Surabaya dianalisa menggunakan analisis bivariat Chi-Square Test dan Fisher Exact Test. Hasil penelitian dari hasil analisis bivariat berdasarkan tabel 4, didapatkan hasil bahwa jenis kelamin tidak berhubungan dengan penyakit diare dalam 3 bulan terakhir. Artinya jenis kelamin tidak berpengaruh pada kejadian diare di Kelurahan Rangkah Buntu, Surabaya.

Variabel usia tidak baru hubungan dengan kejadian diare dalam waktu 3 bulan terakhir. Artinya usia tidak berpengaruh pada kejadian diare di Kelurahan Rangkah Buntu, Surabaya. Variabel tingkat pendidikan tidak berhubungan dengan kejadian diare dalam 3 bulan terakhir. Artinya tingkat pendidikan tidak

Tabel 3. Distribusi Faktor Enabling Factor terhadap Kejadian Diare Rangkah

\begin{tabular}{|c|c|c|c|c|c|c|}
\hline \multirow[t]{2}{*}{ Variabel Independen } & \multicolumn{2}{|c|}{$\begin{array}{l}\text { Kejadian } \\
\text { Diare }\end{array}$} & \multirow{2}{*}{$\begin{array}{l}\text { Chi Square } \\
\text { P-value }\end{array}$} & \multirow{2}{*}{$\begin{array}{c}\text { Fisher } \\
\text { Exact } \\
\text { P-value }\end{array}$} & \multirow[t]{2}{*}{$\mathbf{a}$} & \multirow[t]{2}{*}{ Ket } \\
\hline & Ya & Tidak & & & & \\
\hline \multicolumn{3}{|c|}{ Sarana dan Prasarana Air Bersih } & \multirow{3}{*}{0,732} & \multirow{3}{*}{ - } & \multirow{3}{*}{0,05} & \multirow{3}{*}{$\begin{array}{c}\text { Tidak } \\
\text { memiliki } \\
\text { hubungan }\end{array}$} \\
\hline Ada, Memenuhi syarat & 50 & 129 & & & & \\
\hline $\begin{array}{l}\text { Ada, Namun tidak memenuhi } \\
\text { syarat }\end{array}$ & 8 & 24 & & & & \\
\hline Keadaan Tempat Sampah & & & \multirow{4}{*}{0,284} & \multirow{4}{*}{ - } & & \multirow{4}{*}{$\begin{array}{c}\text { Tidak } \\
\text { memiliki } \\
\text { hubungan }\end{array}$} \\
\hline Ada, Memenuhi syarat & 18 & 64 & & & & \\
\hline Ada, Tidak memenuhi syarat & 37 & 79 & & & & \\
\hline Tidak Ada & 3 & 10 & & & & \\
\hline
\end{tabular}


Tabel 4. Hubungan Variabel Independen Predisposing Factor dengan Kejadian Diare di Kelurahan Rangkah Buntu Tahun 2018.

\begin{tabular}{|c|c|c|c|c|c|c|}
\hline \multirow[b]{2}{*}{ Variabel Independen } & \multicolumn{2}{|c|}{ Kejadian Diare } & \multirow{2}{*}{$\begin{array}{c}\text { Chi } \\
\text { Square } \\
\text { P-value }\end{array}$} & \multirow{2}{*}{$\begin{array}{c}\text { Fisher } \\
\text { Exact } \\
\text { P-value }\end{array}$} & \multirow[b]{2}{*}{$\mathbf{a}$} & \multirow[b]{2}{*}{ Ket } \\
\hline & Ya & Tidak & & & & \\
\hline Jenis Kelamin & & & \multirow{3}{*}{0,689} & \multirow{3}{*}{-} & \multirow{3}{*}{0,05} & Tidak \\
\hline Laki-laki & 8 & 18 & & & & memiliki \\
\hline Perempuan & 50 & 135 & & & & hubungan \\
\hline \multicolumn{6}{|l|}{ Usia } & \multirow{5}{*}{$\begin{array}{c}\text { Tidak } \\
\text { memiliki } \\
\text { hubungan }\end{array}$} \\
\hline 12-17 tahun & 13 & 30 & \multirow{4}{*}{0,099} & \multirow{4}{*}{-} & \multirow{4}{*}{0,05} & \\
\hline 18-40 tahun & 20 & 60 & & & & \\
\hline 41-65 tahun & 14 & 47 & & & & \\
\hline$>66$ tahun & 11 & 16 & & & & \\
\hline \multicolumn{6}{|l|}{ Pendidikan } & \multirow{4}{*}{$\begin{array}{c}\text { Tidak } \\
\text { memiliki } \\
\text { hubungan }\end{array}$} \\
\hline Rendah & 21 & 44 & \multirow{3}{*}{0,517} & \multirow{3}{*}{-} & \multirow{3}{*}{0,05} & \\
\hline Menengah & 9 & 31 & & & & \\
\hline Tinggi & 28 & 78 & & & & \\
\hline \multicolumn{6}{|l|}{ Pendapatan } & \multirow{6}{*}{$\begin{array}{c}\text { Tidak } \\
\text { memiliki } \\
\text { hubungan }\end{array}$} \\
\hline$<500.000$ & 9 & 19 & \multirow{5}{*}{0,332} & \multirow{5}{*}{-} & \multirow{5}{*}{0,05} & \\
\hline $500.000-1.000 .000$ & 7 & 30 & & & & \\
\hline $1.100 .000-1.500 .000$ & 12 & 27 & & & & \\
\hline $1.600 .000-2.000 .000$ & 6 & 28 & & & & \\
\hline$>2.100 .000$ & 24 & 49 & & & & \\
\hline \multicolumn{6}{|l|}{ Pengetahuan } & \multirow{4}{*}{$\begin{array}{c}\text { Tidak } \\
\text { memiliki } \\
\text { hubungan }\end{array}$} \\
\hline Baik & 27 & 86 & \multirow{3}{*}{0,081} & & & \\
\hline Cukup & 15 & 20 & & - & 0,05 & \\
\hline Kurang & 16 & 47 & & & & \\
\hline Sikap (Membersihkan L & kunga & & & & & \\
\hline Baik & 33 & 138 & 0,001 & - & 0,05 & Memilik1 \\
\hline Kurang & 25 & 15 & & & & \\
\hline $\begin{array}{l}\text { Sikap (Membuat dan m } \\
\text { apabila Diare) }\end{array}$ & onsur & ralit & & & & Memiliki \\
\hline Baik & 3 & 44 & 0,001 & - & 0,05 & hubungan \\
\hline Kurang & 55 & 109 & & & & \\
\hline Tindakan (Cuci Tangan & rai Sal & jebelum & & & & \\
\hline Makan) & & & & & 005 & Memiliki \\
\hline Ya & 20 & 29 & $0,0<0$ & - & 0,0כ & hubungan \\
\hline Tidak & 38 & 124 & & & & \\
\hline $\begin{array}{l}\text { Tindakan (Cuci Tangan } \\
\text { BAB) }\end{array}$ & rai Sal & etelah & & & & $\begin{array}{l}\text { Tidak } \\
\text { momiliki }\end{array}$ \\
\hline Ya & 53 & 143 & - & 0,562 & 0,05 & memiliki \\
\hline Tidak & 5 & 10 & & & & \\
\hline
\end{tabular}

berpengaruh pada kejadian diare di Kelurahan Rangkah Buntu, Surabaya.

Variabel tingkat pendapatan tidak berhubungan dengan kejadian diare dalam 3 bulan terakhir. Artinya tingkat pendapatan tidak berpengaruh pada kejadian diare di Kelurahan Rangkah Buntu, Surabaya. Variabel pengetahuan tidak berhubungan dengan kejadian diare dalam 3 bulan terakhir. Artinya pengetahuan tidak berpengaruh pada kejadian diare di Kelurahan Rangkah Buntu, Surabaya.

Ada hubungan antara membersihkan lingkungan dan kejadian diare dalam 3 bulan terakhir. Artinya membersihkan lingkungan memiliki pengaruh pada 
Tabel 5. Hubungan Variabel Independen Enabling Factor dengan Kejadian Diare di Kelurahan Rangkah Buntu Tahun 2018.

\begin{tabular}{lccc}
\hline \multirow{2}{*}{ Variabel Independen } & \multicolumn{2}{c}{ Kejadian Diare } & \multirow{2}{*}{ Total } \\
\cline { 2 - 3 } & Ya & Tidak & \\
\hline Sarana Air Bersih & 50 & 129 & 179 \\
Ada, Memenuhi syarat & 8 & 24 & 32 \\
Ada, Tidak memenuhi syarat & & & \\
\hline Keadaan Tempat Sampah & 18 & 64 & 82 \\
Ada, Memenuhi syarat & 37 & 79 & 116 \\
Ada, Tidak memenuhi syarat & 3 & 10 & 13 \\
Tidak Ada & & & \\
\hline
\end{tabular}

kejadian diare di Kelurahan Rangkah Buntu, Surabaya. Selain itu, ada hubungan antara segera membuat oralit dan kejadian diare dalam 3 bulan terakhir. Artinya segera membuat oralit berpengaruh pada kejadian diare di Kelurahan Rangkah Buntu, Surabaya.

Ada hubungan antara membersihkan tangan dengan sabun sebelum makan dan kejadian diare dalam 3 bulan terakhir. Artinya membersihkan tangan dengan sabun sebelum makan berpengaruh pada kejadian diare di Kelurahan Rangkah Buntu, Surabaya.

Tidak ada hubungan antara membersihkan tangan dengan sabun setelah BAB dan kejadian diare dalam 3 bulan terakhir. Artinya membersihkan tangan dengan sabun setelah BAB tidak berpengaruh pada kejadian diare di Kelurahan Rangkah Buntu, Surabaya. Ketersediaan sarana air bersih tidak berhubungan dengan penyakit diare dalam 3 bulan terakhir. Artinya sarana air bersih tidak berpengaruh pada kejadian diare di Kelurahan Rangkah Buntu, Surabaya.

Tidak ada hubungan antara keadaan tempat sampah dan kejadian diare dalam 3 bulan terakhir. Artinya keadaan tempat sampah tidak berpengaruh pada kejadian diare di Kelurahan Rangkah Buntu, Surabaya.

\section{Predisposing Factor}

\section{Jenis Kelamin}

Jenis kelamin termasuk dalam predisposing factor yang memungkinkan seseorang untuk mengubah perilaku. Perbedaan jenis kelamin mungkin saja bisa membawa pengaruh terhadap individu dalam melakukan aktivitas, sehingga perlu dinilai dan diukur (Notoadmojo, 2007). Data dari Kementrian Kesehatan RI Tahun 2011 menunjukkan bahwa prevalensi diare pada laki-laki adalah 8,9\% dan pada perempuan sebesar 9,1\%. Berdasarkan hasil kuesioner didapatkan responden perempuan yaitu sebanyak 185 warga (88\%) dan sebanyak 50 warga perempuan (24\%) terkena diare dalam 3 bulan terakhir.

Perhitungan statistik pada penelitian ini menggunakan SPSS. Hasil penelitian pada 211 responden warga RW VI tentang hubungan jenis kelamin dengan terjadinya diare diperoleh nilai expected count memenuhi syarat untuk uji chi-square, sehingga didapatkan hasil $p$-value $=0,689$ dengan $a=0,05(p>a)$. Hal ini dapat dikatakan bahwa jenis kelamin tidak berhubungan dengan penyakit diare dalam 3 bulan terakhir. Hal ini sesuai dengan penelitian yang telah dilakukan oleh Mia Kartika pada tahun 2016 yang membuktikan bahwa hasil uji statistik menunjukkan $p$-value sebesar 0,381 , maka dapat ditarik kesimpulan bahwa Ho diterima, artinya jenis kelamin tidak memiliki hubungan dengan kejadian diare.

\section{Usia}

Pada studi epidemologi menyatakan bahwa usia merupakan salah satu karakteristik manusia. Pengertian usia yang dimaksud adalah jumlah usia responden mulai dari lahir hingga dilaksanakannya penelitian ini. Pada penelitian ini usia responden dikategorikan menjadi empat kelompok yaitu 12-17 tahun, 18-40 tahun, 41-65 tahun, dan > 66 tahun. Tabel 2 menunjukkan bahwa mayoritas penduduk warga RW VI, Kelurahan Rangkah, Kecamatan Tambaksari yang terkena diare 
adalah responden dengan kategori usia 1840 tahun sebanyak 20 responden (10\%).

Perhitungan statistik pada penelitian ini menggunakan SPSS. Hasil penelitian pada 211 responden warga RW VI tentang hubungan usia dengan terjadinya diare diperoleh nilai expected count memenuhi syarat untuk uji chi-square, sehingga didapatkan hasil $p$-value $=0,099$. Hal ini menunjukkan bahwa usia tidak memiliki hubungan dengan diare dalam 3 bulan terakhir.

\section{Pendidikan}

Pendidikan secara bahasa berasal dari kata "pedagogi" yakni "paid" yang berarti anak dan "agagos" yang berarti membimbing. Pendidikan memiliki pengertian sebagai ilmu dalam membimbing anak. Hasil penelitian ini menunjukkan bahwa tingkat pendidikan responden dibagi menjadi 3 kelompok yaitu pendidikan rendah, menengah dan tinggi. Kelompok pendidikan rendah yaitu apabila responden berpendidikan terakhir Sekolah Dasar (SD) atau tidak bersekolah sedangkan untuk kelompok pendidikan menengah yaitu apabila responden berpendidikan Sekolah Menengah Pertama (SMP) dan kelompok pendidikan tinggi apabila responden berpendidikan Sekolah Menengah Atas (SMA) maupun Sarjana (D3/S1).

Tabel 2 menunjukkan bahwa responden RW VI, Kelurahan Rangkah, Kecamatan Tambaksari yang terkena diare adalah mayoritas warga dengan berpendidikan tinggi. Perhitungan statistik pada penelitian ini menggunakan SPSS. Hasil penelitian pada 211 responden warga RW VI tentang hubungan usia dengan terjadinya diare diperoleh nilai expected count memenuhi syarat untuk uji chi-square, sehingga didapatkan hasil $p$-value $=0,517$. Hal ini menunjukkan bahwa tingkat pendidikan responden tidak memiliki hubungan dengan kejadian diare dalam 3 bulan terakhir. Teori yang telah ada menunjukkan bahwa semakin tinggi jenjang sekolah seseorang maka sesorang tersebut akan memberi tanggapan yang lebih masuk akal terhadap setiap informasi yang ada dan akan terpikir sampai sejauh mana kelebihan yang mungkin akan didapatkan dari ide tersebut.

\section{Pendapatan}

Pendapatan adalah jumlah uang yang diterima oleh manusia dari kegiatan yang telah dijalaninya yang dapat digunakan untuk konsumsi dan memenuhi kebutuhan sehari hari. Tabel 1 menunjukkan bahwa mayoritas penduduk warga RW VI, Kelurahan Rangkah, Kecamatan Tambaksari yang terkena diare justru para responden dengan tingkat pendapatan tertinggi yaitu diatas $>2.100 .000$ sebanyak 24 responden. Hal ini bisa jadi disebabkan oleh kebiasaan makan, jajan dan minum diluar rumah dikarenakan harus bekerja sehingga kebersihan makanan dan minuman yang dikonsumsi tidak terjamin kebersihannya.

Hasil uji chi-square diperoleh nilai $p$-value pendapatan 0.332 , sehingga dapat disimpulkan bahwa tingkat pendapatan tidak berhubungan dengan penyakit diare dalam 3 bulan terakhir. Hasil tersebut sejalan dengan penelitian yang telah dilakukan oleh Octavia pada tahun 2015 yang membuktikan bahwa pendapatan keluarga tidak memiliki pengaruh terhadap penyakit diare pada balita.

\section{Pengetahuan}

Menurut KBBI, pengetahuan dapat diartikan sebagai segala macam hal yang diketahui, kepintaran. Tabel 2 menunjukkan mayoritas responden memiliki pengetahuan yang baik dan terkena diare dalam 3 bulan terakhir. Sebanyak 27 responden didapatkan hasil $p$-value 0,081 ( $>$ > a), sehingga tidak ada hubungan antara pengetahuan dan kejadian diare dalam 3 bulan terakhir. Hasil ini tidak sejalan dengan penelitian sebelumnya yang telah dibuat oleh Aflia, 2015 yang menunjukkan tingkat pengetahuan responden memiliki hubungan dengan penyakit diare pada anak bawah lima tahun yang mendapatkan hasil signifikansi 0,025 dengan $a=0,05(p<a)$.

\section{Sikap}

Notoatmodjo pada tahun 2012 menyatakan bahwa sikap merupakan respons yang masih tersembunyi dari seorang manusia terhadap stimulus. Sikap dapat diukur secara langsung maupun tidak langsung. Pengukuran sikap merupakan pendapat yang diungkapkan oleh responden terhadap suatu objek 


\section{Membersihkan Lingkungan Sekitar}

Kondisi lingkungan yang buruk adalah salah satu faktor meningkatnya penyakit diare karena mencakup pembuangan tinja, serta ketersediaan sarana dan prasarana air bersih. Hal ini dapat menyebabkan masalah kesehatan lingkungan yang besar karena dapat menyebabkan mewabahnya penyakit diare dan mempengaruhi kondisi kesehatan masyarakat (Fiesta, dkk. 2012).

Tabel 2 menunjukkan bahwa mayoritas responden RW VI, Kelurahan Rangkah, Kecamatan Tambaksari yang terkena diare adalah warga dengan sikap membersihkan lingkungan yang baik sebanyak 33 responden (16\%). Perhitungan statistik pada penelitian ini menggunakan SPSS. Hasil penelitian pada 211 responden warga RW VI tentang hubungan antara membersihkan lingkungan responden dengan kejadian diare diperoleh nilai expected count memenuhi syarat untuk uji chi-square, sehingga didapatkan hasil $p=0,001$. Hal ini dapat diartikan bahwa ada hubungan antara membersihkan lingkungan responden dengan kejadian diare dalam 3 bulan terakhir. Hasil ini sejalan dengan penelitian yang telah dilakukan oleh Tambuwun, dkk pada Tahun 2015 yang menunjukkan bahwa diperoleh nilai signifikan $p=0,001$. Hal ini menunjukkan bahwa sanitasi lingkungan memiliki hubungan dengan penyakit diare pada anak sekolah.

\section{Membuat dan Mengonsumsi Oralit Ketika} Diare

Menurut $\mathrm{KBBI}$ oralit adalah obat berupa bubuk garam untuk dicairkan sebagai pengganti mineral dan cairan yang keluar akibat penyakit muntah ataupun berak. Larutan oralit mempunyai komposisi campuran garam, gula serta natrium bikarbonat. Kejadian kematian anak dengan diare dikarenakan komplikasi dehidrasi yang ditimbulkan dan penanganan yang kurang tepat. WHO dan UNICEF telah mengeluarkan formula baru dengan osmolaritas lebih rendah yaitu $245 \mathrm{mOsm} / \mathrm{L}$ yang memberikan efek lebih aman terhadap semua jenis diare non kolera dengan dehidrasi.

Tabel 2 di atas menunjukkan bahwa kebanyakan responden RW VI, Kelurahan Rangkah, Kecamatan Tambaksari yang terkena diare adalah mayoritas warga dengan sikap mengonsumsi oralit yang kurang baik yaitu sebanyak 55 responden (26\%). Perhitungan statistik pada penelitian ini menggunakan SPSS. Hasil penelitian pada 211 responden warga RW VI tentang hubungan membersihkan lingkungan dengan terjadinya diare diperoleh nilai expected count memenuhi syarat untuk uji chi-square sehingga didapatkan hasil $p$-value $=0,001$. Hal ini menunjukkan bahwa terdapat hubungan antar mengonsumsi oralit responden dengan kejadian diare dalam 3 bulan terakhir.

Hasil ini sejalan dengan penelitian yang telah dilakukan oleh Puji dan Yuniar (2017) yang berjudul “Pengaruh Oralit 200 terhadap Lama Perawatan Bayi Dengan Kejadian Diare Akut Dehidrasi Ringan Sedang". Penelitian tersebut menunjukkan bahwa ada pengaruh Pemberian oralit 200 juga memberikan pengaruh terhadap konsistensi feces dan penurunan frekuensi buang air besar pada bayi dengan diare akut dehidrasi ringan-sedang. Nilai $p$-value yang diperoleh adalah 0,004. Nilai ini menunjukkan bahwa ada korelasi antar perlakuan oralit 200 terhadap konsistensi feces.

\section{Perilaku Mencuci Tangan Menggunakan Sabun}

Kebiasaan membersihkan tangan menggunakan sabun sebaiknya dibiasakan sejak dini. Hal tersebut dipengaruhi oleh faktor lingkungan, yaitu keluarga. Keluarga juga dapat menumbuhkan sikap perilaku cuci tangan. Data Riset Kesehatan Dasar RI menjelaskan bahwa 100.000 anak meninggal dunia karena diare tiap tahunnya.

\section{Perilaku Mencuci Tangan Menggunakan Sabun Sebelum Makan dengan Kejadian Diare}

Salah satu cara untuk menurunkan penyakit diare adalah dengan cara mencuci tangan menggunakan sabun. Mencuci tangan dengan sabun dapat menghilangkan kuman penyebab diare. Kuman diare tersebut biasanya menyebar melalui makanan dan minuman yang terkontaminasi serta kontak langsung dengan orang yang terinfeksi.

Hasil penelitian terhadap responden didapatkan bahwa kesadaran perilaku untuk melakukan cuci tangan pakai sabun sebelum makan masih tergolong rendah. 
Hal ini dibuktikan dengan sebanyak $77 \%$ responden tidak mencuci tangannya dengan sabun sebelum makan. Perilaku masyarakat yang tidak melakukan cuci tangan pakai sabun dapat memicu timbulnya diare. Cuci tangan pakai sabun dengan benar dapat menurunkan angka kejadian diare hingga $45 \%$, karena apabila cuci tangan pakai sabun dengan benar dapat membunuh kuman di tangan sehingga ketika makan kuman tersebut tidak masuk ke dalam tubuh bersama makanan yang dimakan.

Tabel 2 menunjukkan bahwa terdapat 38 warga $(18 \%)$ yang terkena diare. Hal tersebut karena masyarakat tidak memiliki kebiasaan mencuci tangan dengan sabun sebelum makan. Penelitian ini berhubungan dengan penelitian yang menyatakan bahwa kuman penyebab diare menyebar melalui makanan dan minuman yang tercemar.

Perhitungan statistik pada penelitian ini menggunakan SPSS. Hasil penelitian pada 211 responden warga RW VI tentang hubungan antara perilaku mencuci tangan menggunakan sabun sebelum mengonsumsi makanan dengan terjadinya diare diperoleh nilai expected count memenuhi syarat untuk uji chi-square. Nilai yang diperoleh $p=0,028$. Hal ini menunjukkan bahwa perilaku membersihkan tangan dengan sabun memiliki hubungan dengan penyakit diare dalam 3 bulan terakhir.

Semakin baik perilaku CTPS maka akan semakin rendah tingkat kejadian diare begitu pula sebaliknya. Hasil di atas sesuai dengan penelitian Arry, dkk pada tahun 2013 yang memperoleh hasil $p$-value 0,008 . Hasil ini menunjukkan bahwa membersihkan tangan menggunakan sabun memiliki hubungan dengan penyakit diare anak sekolah di Kabupaten Blora.

Hubungan Perilaku Cuci Tangan dengan Sabun Setelah Buang Air Besar dengan Kejadian Diare

Penyakit diare dapat berupa infeksi yang disebabkan oleh virus, bakteri dan lain sebagainya. Penyakit ini juga termasuk dalam water borne diseases. Water Borne Disease adalah cara penyebaran penyakit dimana mikrooganisme patogen ditularkan atau pindah secara langsung ketika air yang telah terkontaminasi tersebut dikonsumsi. Kuman tersebut tidak akan masuk ke tubuh jika mencuci tangan pakai sabun dengan benar.

Hasil penelitian yang dilakukan terhadap 211 responden didapatkan hasil yang cukup baik, yaitu sebanyak 196 responden $(92 \%)$ telah melakukan membersihkan tangan dengan sabun setelah buang air besar, namun masih ada juga warga yang tidak mencuci tangan dengan sabun sesudah buang air besar.

Perilaku membersihkan tangan menggunakan sabun sesudah buang air besar termasuk dalam 5 waktu yang dianjurkan untuk melakukan cuci tangan selain setelah memegang hewan peliharaan, sebelum menyiapkan makanan, setelah membersihkan anak bayi, dan sebelum makan. Perilaku masyarakat yang membersihkan tangan dengan sabun setelah buang air besar dapat menurunkan kasus kematian akibat diare. Mencuci tangan dengan sabun adalah perlindungan penting karena mencegah kuman patogen dari lingkungan dan makanan (WHO, 2014).

Tabel 2 menunjukkan bahwa terdapat 58 warga $(28 \%)$ yang terkena penyakit diare dikarenakan tidak memiliki perilaku CTPS setelah buang air besar karena tidak terbiasa untuk mencuci tangan menggunakan sabun. Penelitian ini berhubungan dengan penelitian yang menyatakan kuman penyebab diare dapat masuk ke dalam tubuh melalui makanan dan minuman yang tercemar.

Hal tersebut bertolak belakang dengan hasil penelitian pada 211 responden warga RW VI, tentang hubungan antara perilaku cuci tangan pakai sabun setelah buang air besar dengan terjadinya diare, maka dilakukan tabulasi silang pada program SPSS, nilai expected count tidak memenuhi syarat untuk uji chi-square sehingga menggunakan uji fisher exact dan didapatkan hasil $p$-value $=0,562$ ini berarti bahwa perilaku cuci tangan pakai sabun setelah buang air besar tidak memiliki hubungan dengan penyakit diare dalam 3 bulan terakhir. Namun hal tersebut dapat dikarenakan bermacam macam faktor, misalnya tidak makan walaupun setelah buang air besar sebagai faktor confounding dalam variabel tersebut.

Hal ini tidak sejalan dengan penelitian oleh Rafri (2016) tentang perilaku mencuci 
J urnal Promkes: The Indonesian J ournal of Health Promotion and Health Education Vol. 7 No. 1 (2019) 34-45. doi: 10.20473/jpk.V7.I1.2019.34-45

tangan dan kejadian diare pada anak usia pra sekolah di PAUD Desa Kalikotes Klaten yang mendapat hasil pengujian nilai sebesar 16,476 dengan nilai probabilitas $<$ 0,05 yakni 0,001 maka Ho ditolak, yang artinya perilaku mencuci tangan memiliki hubungan dengan penyakit diare.

\section{Enabling Factor}

\section{Sarana Air Bersih}

Sumber air bersih yang digunakan oleh responden mayoritas bersumber dari sumur dan sebagian berasal dari air PDAM. Tabel 5 menunjukkan terdapat 8 responden (4\%) yang terkena diare dikarenakan memiliki sarana air bersih yang tidak memenuhi syarat. Perhitungan statistik pada penelitian ini menggunakan SPSS. Hasil penelitian pada 211 responden warga RW VI tentang sarana air bersih dengan terjadinya diare, diperoleh nilai expected count memenuhi persyaratan untuk dilakukan uji chi-square dengan $p$-value $=0,732$. Hal ini menunjukkan bahwa tidak terdapat hubungan antara sarana air bersih dengan terjadinya diare dalam 3 bulan terakhir. Penelitian ini tidak sejalan dengan Oktavia dan Puteri pada tahun 2016 yang memperoleh hasil $\mathrm{p}=0,04$ maka antara kondisi sarana dan prasarana air bersih memiliki hubungan penyakit diare pada bayi.

\section{Keadaan Tempat Sampah}

Banyak tempat sampah belum memenuhi syarat yang ditemukan di lingkungan responden. Kondisi tempat sampah yang belum memengaruhi syarat tersebut adalah tempat sampah yang belum terpisah antara sampah basah dan kering. Responden menggunakan kantong plastik sebagai tempat penampungan sampah sementara di dapur lebih dari sehari, dan tempat sampah tidak memiliki penutup. Penumpukan sampah baik di kantong plastik atau berserakan di tanah merupakan tempat perkembangbiakan nyamuk, lalat dan kecoa sebagai vektor penyakit malaria, disentri dan diare dan dapat menimbulkan polusi air dan tanah (Patricia dkk, 2013).

Tabel 3 menunjukkan terdapat 37 responden (18\%) yang terkena diare dikarenakan memiliki tempat sampah namun tidak memenuhi syarat. Perhitungan statistik pada penelitian ini menggunakan
SPSS. Hasil penelitian pada 211 responden warga RW VI tentang kondisi tempat sampah dengan terjadinya diare diperoleh nilai expected count layak untuk dilakukan chi-square dan diperoleh $p$-value $=0,284$. Hal ini menunjukkan bahwa antara kondisi tempat sampah tidak memiliki hubungan dengan terjadinya penyakit diare dalam 3 bulan terakhir.

Hasil tersebut bertolak belakang dengan penelitian yang dilakukan oleh Oktavia dan Puteri pada Tahun 2016. Penelitian tersebut menggunakan chisquare, diperoleh p-value 0,045 maka Ho ditolak. Hal tersebut artinya variabel kondisi tempat sampah memiliki kaitan terhadap penyakit diare dengan dehidrasi sedang pada balita di Kota Semarang pada tahun 2015.

\section{SIMPULAN}

Hasil penelitian di atas menunjukkan bahwa tidak terdapat hubungan antara jenis kelamin, usia, pendidikan, pendapatan, perilaku CTPS setelah buang air besar, sarana air bersih serta kondisi tempat sampah dengan penyakit diare selama 3 bulan terakhir di wilayah RW. VI Kelurahan Rangkah Buntu, Kota Surabaya. Terdapat hubungan yang signifikan antara membersihkan lingkungan, membuat dan mengonsumsi oralit, dan perilaku mencuci tangan menggunakan sabun sebelum makan dengan penyakit diare selama 3 bulan terakhir di wilayah RW. VI Kelurahan Rangkah Buntu, Kota Surabaya.

\section{DAFTAR PUSTAKA}

Anik,dkk. 2017. Hubungan Antara Perilaku Cuci Tangan Dengan Kejadian Diare Pada Anak SD. Jurnal Penelitian. STIKES PKU Muhammadiyah Surakarta Prodi DIII Keperawatan.

Arry, dkk. 2013. Hubungan Perilaku Cuci Tangan Pakai Sabun Dengan Kejadian Diare Anak Usia Sekolah di SDN 02 Pelemsengir Kecamatan Todanan Kabupaten Blora. Jurnal Keperawatan Vol.6 No. 1 Maret 2013: 15-23. Fakultas Ilmu Keperawatan dan Kesehatan Universitas Muhammadiyah Semarang.

Dinkes Jawa Timur. 2016. Profil Kesehatan Provinsi Jawa Timur Tahun 2016. Sitasi 19 Februari 2018. 
Dinkes Kota Surabaya. 2015. Profil Kesehatan Kota Surabaya Tahun 2015. Sitasi 19 Februari 2018

Dewi, Oktavia dan Puteri Hidayati. 2016. Hubungan Sanitasi Dasar Lingkungan Dengan Kejadian Diare Pada Bayi di Wilayah Kerja Puskesmas Rejosari Kota Pekanbaru. [Naskah Publikasi]. Program Doktor Ilmu Lingkungan Universitas Riau.

Fiesta O.S., dkk. 2012. Hubungan kondisi lingkungan perumahan dengan kejadian diare di desa sialang buah kecamatan teluk mengkudu kabupaten serdang bedagai Tahun 2012. Jurnal Lingkungan dan Kesehatan Kerja Vol 2 No 3 (2013). Universitas Sumatera Utara

Ilham,dkk. 2014. Hubungan Perilaku Cuci Tangan Pakai Sabun Dengan Kejadian Diare Di Sd Advent Sario Kota Manado. Jurnal Kedokteran Komunitas dan Tropik: Volume 2 Nomor 3 Agustus 2014. Universitas Sam Ratulangi.

Indriyani, Puji dan Yuniar Deddy Kurniawan. 2017. Pengaruh Oralit 200 Terhadap Lama Perawatan Bayi Dengan Kejadian Diare Akut Dehidrasi Ringan - Sedang 30 September 2017. [Naskah Publikasi]. Akper Yakpermas Banyuwangi

Kolopaking, M.S. 2003. Pendekatan Diagnosis Diare Kronik. Buku Ajar Ilmu Penyakit Dalam Jilid II. Ed: Suyono S. 2nd. Jakarta: Balai Penerbit FKUI.

Kementrian Kesehatan RI. 2016. Profil Kesehatan Indonesia Tahun 2016. Sitasi 19 Februari 2018.

Mandasari, Dessy Apriliya. 2017. Perbedaan faktor yang mempengaruhi kejadian diare pada balita di pesisir pantai Kabupaten Situbondo dan di Peddesaan Kabupaten Bondowoso. [Thesis]. Surabaya: Fakultas Kesehatan Masyarakat Universitas Airlangga.

Marissa, Octavia Julia. 2015. Hubungan Sanitasi Lingkungan, Sosial Ekonomi, dan Perilaku Ibu Terhadap Kejadian Diare Dengan Dehidrasi Sedang Pada Balita di Wilayah Puskesmas Mangkang Kota Semarang Tahun 2015. [Skripsi]. Semarang: Jurusan Ilmu Kesehatan Masyarakat Fakultas Ilmu Keolahragaan Universitas Negeri Semarang.
Mia, dkk. 2016. Faktor-Faktor yang Berhubungan Dengan Perilaku Cuci Tangan Pakai Sabun pada Siswa Sekolah Dasar Negeri Sambiroto 01 Kota Semarang. Jurnal Kesehatan Masyarakat Vol. 4 No 5 oktober 2016. Fakultas Kesehatan Masyarakat Universitas Diponegoro Semarang.

Notoatmodjo, S. 2007. Pendidikan dan Perilaku Kesehatan. Jakarta: Rineka Cipta.

Noor, N.N., 2008. Epidemiologi. Jakarta: Rineka Cipta.

Purnomo, Rafri Aditya. 2016. Perilaku mencuci tangan dan kejadian diare pada anak usia pra sekolah di paud desa Kalikotes Klaten. [Naskah Publikasi]. Fakultas IImu Kesehatan Universitas Muhammadiyah Surakarta.

Rachmayanti. 2013. Penggunaan Media Panggung Dalam Pendidikan Personal Hygiene Cuci Tangan Menggunakan Sabun di Air Mengalir. Jurnal Promkes Vol 1, No 1 (2013). Fakultas Kesehatan Masyarakat Universitas Airlangga.

Tambuwun, dkk. 2015. Hubungan Sanitasi Lingkungan dengan Kejadian Diare Pada Anak Usia Sekolah di Wilayah Kerja Puskesmas Bahu Manado. Volume 3 Nomor 2 Mei 2015. Jurnal Keperawatan Vol 3 No 2 (2015). Fakultas Kedokteran Universitas Sam Ratulangi.

Wati, Aflia. 2015. Hubungan Pengetahuan yang menunjukkan ada hubungan yang singnifikan antara hubungan pengetahuan dengan kejadian diare pada balita di Wilayah Kerja Puskesmas Titeu Kecamatan Titeu Kabupaten Pidie Tahun 2015. [Skripsi]. Banda Aceh: Fakultas Ilmu Kesehatan Universitas Ubudiyah Indonesia.

Wibowo, Arief. 2008. Catatan Kuliah Biostatistika Non Parametrik. Fakultas Kesehatan Masyarakat Universitas Airlangga Surabaya. 